\title{
Comparative Study of Individual and Hybrid Renewable Energy Systems (Photovoltaic, Wind Energy and Hybridization). Controlled by Fuzzy Logic Control
}

\author{
Zahira Bouguerra and Arezki Benfdila* \\ Micro and Nanoelectronics Research Group, Faculty of Electrical Engineering and Computer Sciences, University Mouloud Mammeri, \\ Tizi-Ouzou, Algeria
}

Received 25 October 2021; Accepted 25 November 2021

\begin{abstract}
The present paper describes and evaluates the performances of individual sources of photovoltaic system (PV), wind energy conversion based on permanent magnet synchronous generator (PMSG), and hybrid system that combines both sources (PV/WEC). This is done to determine which of them would be more efficient to provide reliable power with better performances based on their performances comparison. A fuzzy logic control (FLC) is used to maximize the output power of each of the mentioned systems. For the grid connection, an inverter is used to interconnect the systems controlled by the field oriented control (FOC) technique. The FOC technique aims to efficiently decouple the active and reactive powers and achieve a constant DC output voltage with a better power factor. Modeling using different control strategies has been thoroughly examined and discussed. The effectiveness of the control techniques was tested using MTLAB/Simulink software under varying conditions of sunlight, wind speed and output load adjustment. The simulation results confirmed the hybrid system higher efficiency and ability to supply a reliable power. The FLC controller robustness emphasized the instantaneous variation of weather variations and the feasibility of the decoupled control to guarantee a unity power factor.
\end{abstract}

Keywords: Photovoltaic system, Wind Energy conversion, PMSG, Fuzzy logic control, Field oriented control

\section{Introduction}

Renewable energy market grows regularly in the decades [1, 2] aiming completion with carbon limits and replacement of fossil energies. Photovoltaic and wind energies have received great attention in electrical energy production these last decades. However, these energies are highly dependent on weather conditions (sunlight, temperature and wind speed). Therefore the energy supplied to the grid fluctuates and negatively affects the grid system functioning. To overcome this dependence, a common solution consisting on multiple resources combination such s PV-wind hybrid system is proposed. Its connection to the grid system ensures a continuous supply electrical energy regardless of external changes. Moreover, PV and wind power energies are complementary: sunny days are usually calm and strong winds are often occurring during cloudy days or nighttimes $[3,4]$. The hybrid PV/wind integrated system is found to provide high steady state power generation. Renewable energy systems are linked to a network seen as a virtual storage system through a controllable inverter. The excess power will be injected to a grid system that will cover a power deficit when load requirements exceed the supplied hybrid power using modern power converters of high efficiency that is in the $95 \%$ order $[5,6]$.

In [7], a composite sliding mode controller (CMSC) is developed to regulate the WEC by combining a speed control and a disturbance observer loops to reduce the chattering problem. Perturbed and Observed (P\&O) methods are used to control PV system. After comparison, the CSMC demonstrated its efficacy in reducing higher ripples in sliding mode controllers (SMC). A comparative study of few MPPT methods is investigated in [8]. Results comparison between $\mathrm{P} \& \mathrm{O}$, sliding mode (SMC) control and FLC has been achieved, and the FLC method is found more efficient $(99.45 \%)$ than the others. In [9], a signal MPPT controller based on Neural Network methods (NN) to command the PV and WECs system simultaneously has been used. In [10], the hybrid system of Photovoltaic (PV) station and WEC farm interconnected to the main AC bus is described. The simulations results are found to be in a good agreement, however, the total coast is higher and complex as the system contained more electrical equipments. In refs [11-14] different results have been shown and compared to illustrate the importance of the PV-Wind hybrid systems efficiency.

\section{System Configuration}

The figures below show the different systems configuration studied in this work. Figure 1 illustrates the PV system consisting of a PV generator and a boost-converter controlled by FLC control. The WEC (Wind Energy Converter) system is shown in Fig.2. It consists of a PMSG derived by a wind turbine and connected to a boostconverter controlled by an FLC to track the WEC optimal power. Figure 3 describes the hybrid system that combines the PV and WEC systems, which are interconnected to the common DC bus via two boost converters. For the grid connection, AC/DC inverter controlled by field oriented control (FOC) is used to control separately the two powers injected to the grid. 


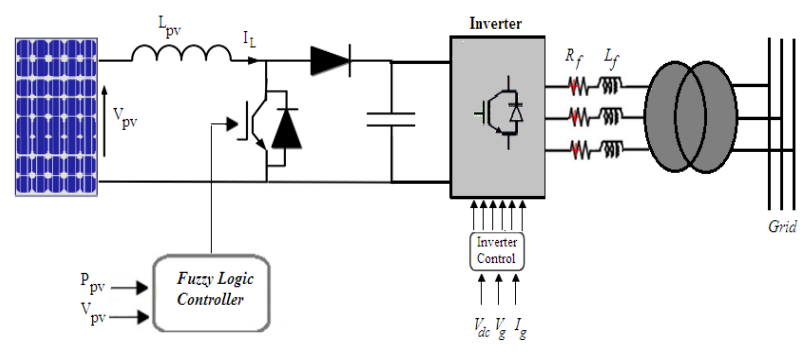

Fig. 1. Photovoltaic Conversion System

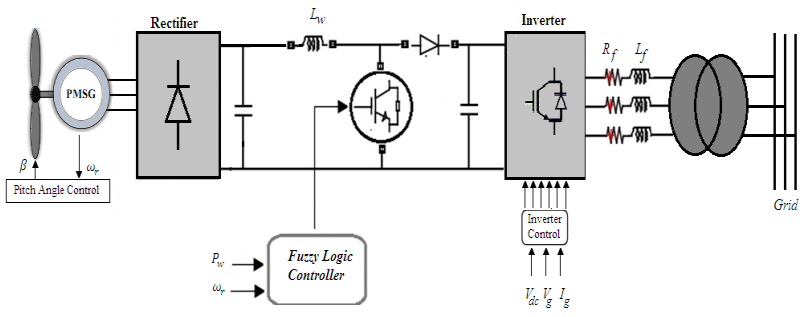

Fig. 2. WEC System

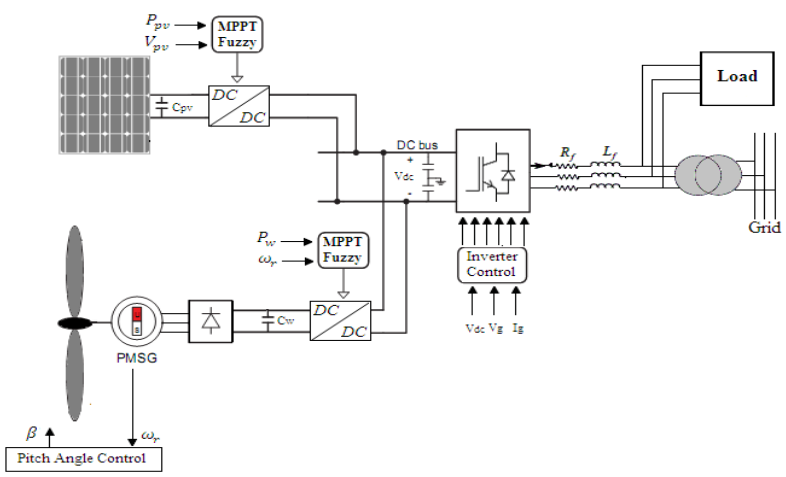

Fig. 3. PV/WEC Hybrid System

\section{Conversion System Modelling}

\subsection{PV Conversion System}

Solar PVs convert the irradiation into electricity using the photoelectric effect. The real circuit of PV cell is shown schematically in Fig. 4.

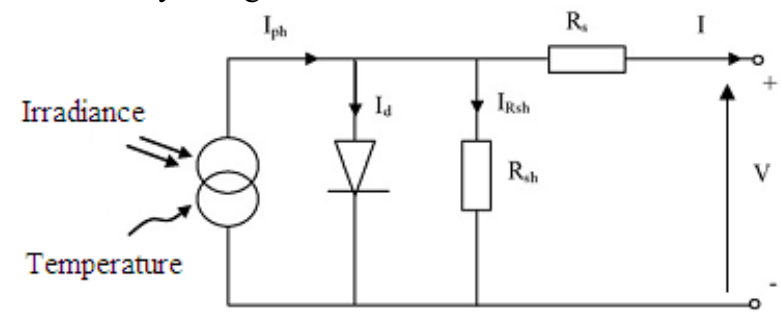

Fig. 4. Solar cell Equivalent Circuit

When sunlight is incident on the PV cell, a certain $\mathrm{I}_{\mathrm{pv}}$ current is generated. This current is given by the following equation [15]:

$I_{p v}=I_{p h}-I_{o}\left[\exp \left(\frac{V+I R_{S}}{a}\right)-1\right]-\frac{V+I R_{S}}{R_{s h}}$

$a=\frac{n k T}{q}$

Where: $\mathrm{I}_{\mathrm{ph}}$ : photo-current, $\mathrm{I}_{\mathrm{o}}$ : saturation current, $\mathrm{q}$ electron charge, $\mathrm{k}$ Boltzmann constant, $a$ is the ideality factor, $R_{s}$ series resistance, $R_{\text {sh }}$ shunt resistance, and $T$ the temperature.

Because the PV panel arrays are easily affected by the environmental conditions, the PV operating point may change [16]. Therefore, the use of control techniques to maximize the output power and improve the PV efficiency is needed. Due to its high efficiency and performance under external changes, the FLC technique became one of the most widely used controller in renewable energy systems. In addition, this technique tracks the maximum power under partial shading weather conditions compared to other computing methods $[17,18]$. The FLC controller is an intelligent controller able to split a complex system into different subsystems according to available data after going through three steps that are: fuzzification, inference and defuzzification. The proposed FLC controller is shown in Fig. 5.

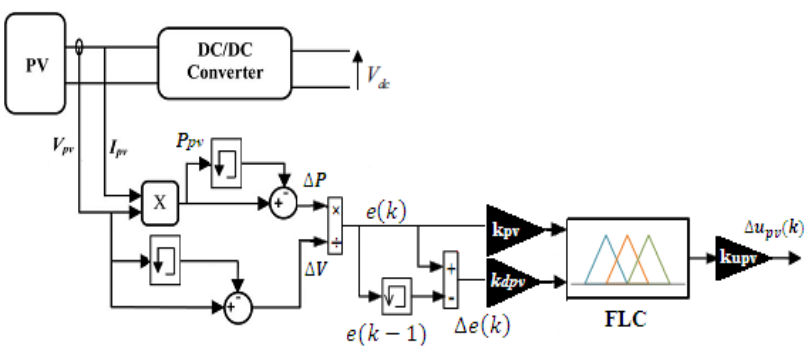

Fig. 5. FLC Structure Used for PV Systems

The FLC has tow inputs $(\mathrm{e}, \Delta \mathrm{e})$ with single output $\left(\Delta \mathrm{u}_{\mathrm{pv}}\right)$ as shown in Figs. 6 and 7 . After an input variations (power and voltage), the output is determined and given in table 1 . The symbols NG, N, ZE, P, PG means respectively: Negative Great, Negative Zero, Positive and Positive Great.

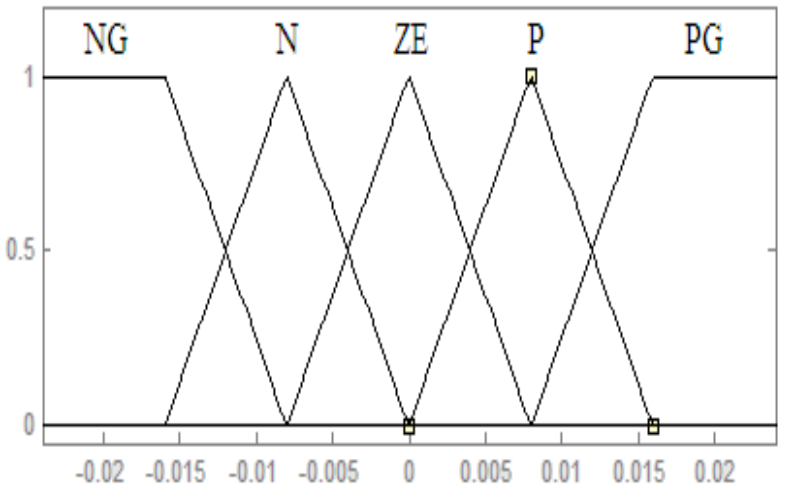

Fig. 6. e, $\Delta$ e Membership Functions

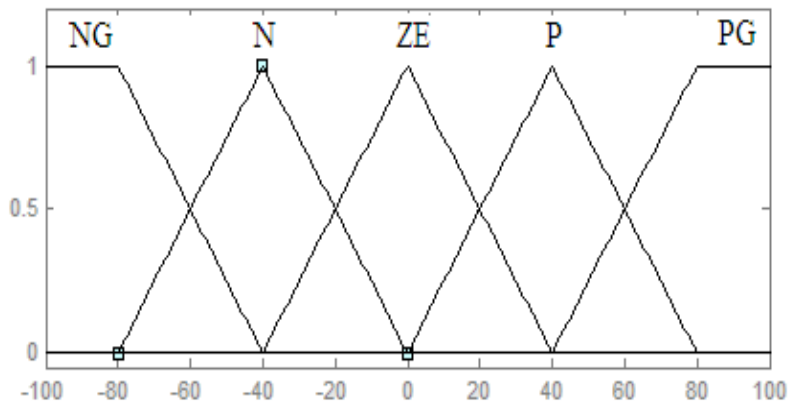

Fig. 7. $\Delta \mathrm{u}_{\mathrm{pv}}$ Membership Functions 
Table 1. Basic Rules

\begin{tabular}{|c|l|l|l|l|l|l|}
\hline \multicolumn{2}{|c|}{$\Delta u_{p v}$} & \multicolumn{5}{c|}{$\Delta e$} \\
\cline { 3 - 7 } & NG & N & ZE & P & PG \\
\hline \multirow{4}{*}{$e$} & NG & ZE & ZE & PG & PG & PG \\
\cline { 2 - 7 } & $\mathrm{N}$ & ZE & ZE & P & P & P \\
\cline { 2 - 7 } & ZE & $\mathrm{P}$ & ZE & ZE & ZE & N \\
\cline { 2 - 7 } & $\mathrm{P}$ & $\mathrm{N}$ & $\mathrm{P}$ & $\mathrm{N}$ & ZE & ZE \\
\cline { 2 - 7 } & $\mathrm{PB}$ & $\mathrm{NG}$ & $\mathrm{NG}$ & $\mathrm{NG}$ & $\mathrm{ZE}$ & ZE \\
\hline
\end{tabular}

\subsection{Wind Energy Conversion Principles}

The wind forces turn the turbine blades that induce a shaft rotation. The PMSG converts this mechanical rotation to electrical power. The power recovered by the turbine is given by (3) [19]:

$P_{t}=\frac{1}{2} C_{p}(\lambda, \beta) \cdot \rho \cdot \pi \cdot R^{2} \cdot v_{\text {wind }}^{3}$

The power coefficient is given by the equation (4) [20]:

$C_{p}(\lambda, \beta)=C_{1}\left(\frac{C_{2}}{\lambda_{i}}-C_{3} \beta-C_{4}\right) e^{\frac{-C_{5}}{\lambda_{i}}}+C_{6}$

With:

$\lambda=\frac{R \cdot \omega_{r}}{v_{\text {wind }}}$

$\frac{1}{\lambda_{i}}=\frac{1}{\lambda+0.08 \beta}-\frac{0.035}{\beta^{3}+1}$

$\mathrm{C}_{1}=0.5176, \mathrm{C}_{2}=116, \mathrm{C}_{3}=0.4, \mathrm{C}_{4}=5, \mathrm{C}_{5}=21$ and $\mathrm{C}_{6}=0.0068$

In wind variable speed controllers, the PMSG is the widely used generator due to its major advantages. It shows better performances due to higher efficiency and less maintenance time as it does not involve a rotor current [21]. The PMSG model is described by the following equation [22]:

$\left\{\begin{array}{c}V_{d}=R_{s} I_{d}+L_{d} \frac{d}{d t} I_{d}-\omega_{e} L_{q} I_{q} \\ V_{q}=R_{s} I_{q}+L_{q} \frac{d}{d t} I_{q}+\omega_{r} L_{d} I_{d}+\omega_{e} \emptyset_{f}\end{array}\right.$

The electromagnetic torque is given in the equation (8) [23]:

$C_{e m}=\frac{3}{2} p \emptyset_{f} i_{q}$

Where: $\mathrm{I}_{\mathrm{d}}, \mathrm{I}_{\mathrm{q}}, V_{d}, V_{q}$ respectively the stator currents and voltages in $(\mathrm{d}, \mathrm{q})$ reference, $\mathrm{R}_{\mathrm{s}}$ the stator resistance, $\mathrm{L}_{\mathrm{d}}, \mathrm{L}_{\mathrm{q}}$ the d_q axis inductance, $\emptyset_{f}$ the permanent magnetic flux, $\omega_{r}$ the generator electrical rotating speed $\left(\omega_{e}=p \omega_{r}\right)$ and $\mathrm{p}$ the number of poles, and $\omega_{r}$ the turbine speed.

WEC observe low cost installation and environment friendly nature but suffer from low-efficiency due to varying wind speed [24]. The wind varying conditions and uncertainty will constrain the system operations [25]. Therefore, different MPPT methods are used to operate the WEC power system at maximum efficiency. FLC is the most used controller in renewable energy because of rapid variations with weather conditions. Its schematic diagram is detailed in Fig. 8.

The memberships function and rules base is shown in Fig.9 and in Table. 2. The characters NG, N, ZE, P, PG means respectively Negative great, negative, Zero, Positive, Positive great.

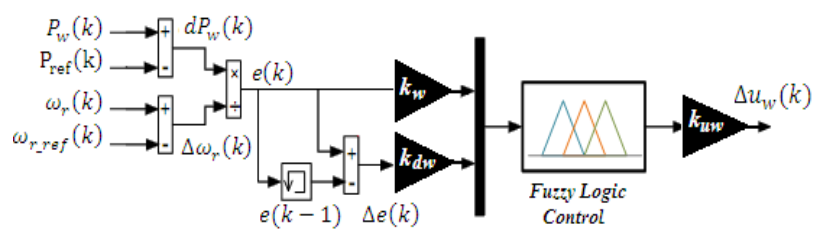

Fig. 8. FLC Controller of WEC

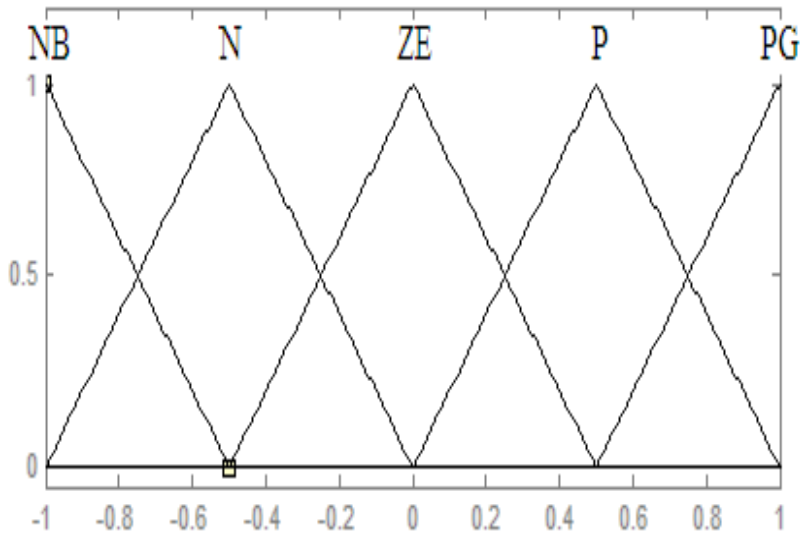

Fig. 9. Inputs \& Output Membership Functions $\left(e, \Delta e, \Delta u_{w}\right)$

Table 2. Basic Rules

\begin{tabular}{|c|c|c|c|c|c|c|}
\hline \multicolumn{2}{|c|}{$\Delta u_{w}$} & \multicolumn{5}{|c|}{$\Delta e$} \\
\cline { 2 - 7 } \multicolumn{2}{|c|}{$e$} & $\mathrm{NG}$ & $\mathrm{N}$ & $\mathrm{ZE}$ & $\mathrm{P}$ & $\mathrm{PG}$ \\
\hline \multirow{4}{*}{$e$} & $\mathrm{NG}$ & $\mathrm{NG}$ & $\mathrm{NG}$ & $\mathrm{N}$ & $\mathrm{N}$ & $\mathrm{ZE}$ \\
\cline { 2 - 7 } & $\mathrm{N}$ & $\mathrm{NG}$ & $\mathrm{N}$ & $\mathrm{N}$ & $\mathrm{ZE}$ & $\mathrm{P}$ \\
\cline { 2 - 7 } & $\mathrm{ZE}$ & $\mathrm{P}$ & $\mathrm{N}$ & $\mathrm{ZE}$ & $\mathrm{P}$ & $\mathrm{P}$ \\
\cline { 2 - 7 } & $\mathrm{P}$ & $\mathrm{N}$ & $\mathrm{ZE}$ & $\mathrm{N}$ & $\mathrm{ZE}$ & $\mathrm{ZE}$ \\
\cline { 2 - 7 } & $\mathrm{PG}$ & $\mathrm{ZE}$ & $\mathrm{P}$ & $\mathrm{P}$ & $\mathrm{PG}$ & $\mathrm{PG}$ \\
\hline
\end{tabular}

The pitch angle controller is usually applied to limit the turbine output power to a medium value for large wind turbines [26]. This controller adjusts continuously the PMSG rotating speed for maximum output power. The FLC technique used to control the pitch angle is illustrated in Fig. 10.

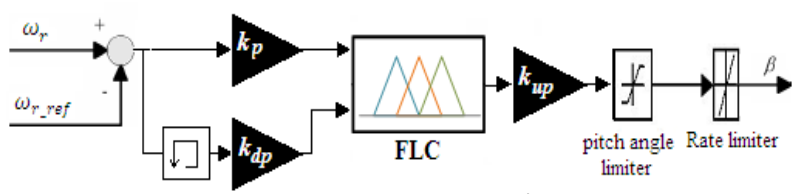

Fig. 10. Pitch Angle Controller

\subsection{Grid side Power Control}

Figure 11 illustrated the schema of inverter control applied for three systems, which aims to separate control of active and reactive powers. Therefore, the $\mathrm{d}-\mathrm{q}$ reference rotation is applied, by aligning the $\mathrm{d}$ axis with the grid voltage while $\mathrm{V}_{\mathrm{q}}$ is to zero. Then, the powers injected into the grid $(\mathrm{P}, \mathrm{Q})$ will be controlled independently by $I_{d}$ and $I_{q}$ currents ,respectively. So, the $\mathrm{P}, \mathrm{Q}$ powers can be expressed in the equation (9) and (10) [27]:

$P=\frac{3}{2} V_{d g} I_{d g}$ 
$Q=\frac{3}{2} V_{d g} I_{q g}$

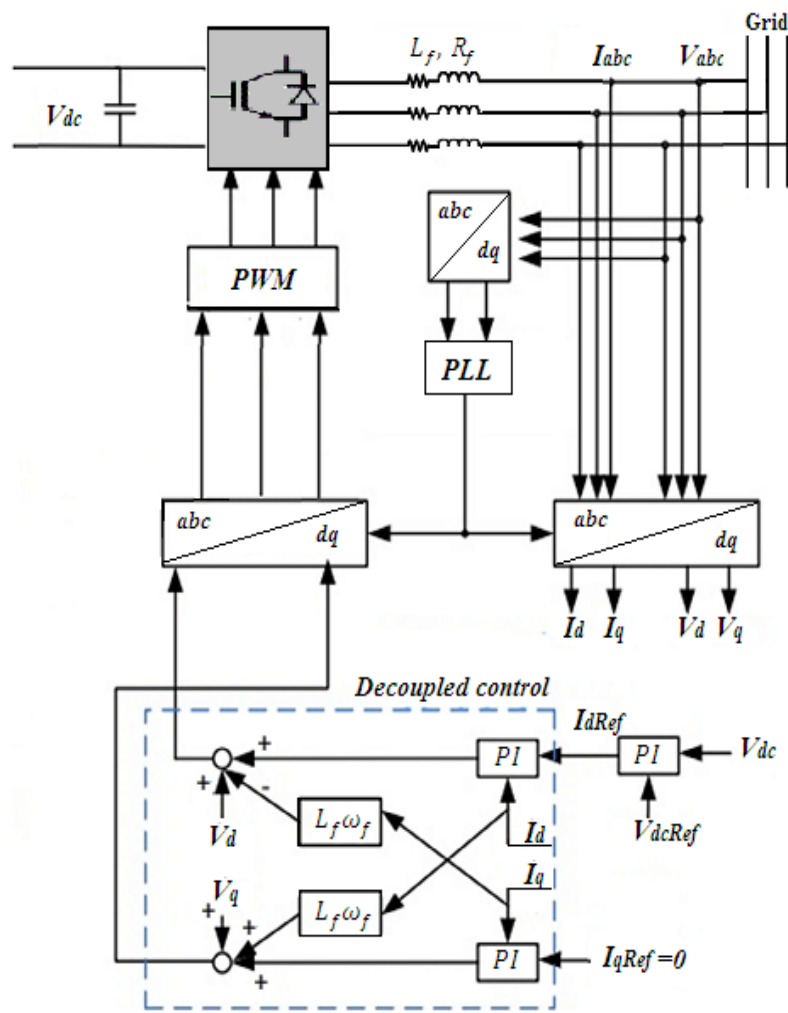

Fig. 11. Inverter Control System

\section{Results and Discusions}

The simulations of each of the systems (PV, WEC and $\mathrm{PV} / \mathrm{WEC}$ ) under wind speed and irradiation variations, and load demand are described bellow and their parameters are listed in Table 3.

Table 3. Converter System Parameters

\begin{tabular}{|c|c|c|c|}
\hline \multicolumn{2}{|c|}{ PV Module } & \multicolumn{2}{|c|}{ PMSG } \\
\hline Maximum power & $200 \mathrm{~W}$ & $\begin{array}{l}\text { Nber of } \\
\text { pole pairs }\end{array}$ & $\mathrm{p}=5$ \\
\hline Optimal current & $8.21 \mathrm{~A}$ & $\begin{array}{l}\text { Stator } \\
\text { resistance }\end{array}$ & $0.425 \Omega$ \\
\hline Optimal voltage & $32.9 \mathrm{~V}$ & $\begin{array}{l}\text { Armature } \\
\text { resistance }\end{array}$ & $0.0082 \Omega$ \\
\hline \multicolumn{2}{|c|}{ Wind turbine } & $\begin{array}{l}\text { Fractional } \\
\text { factor }\end{array}$ & $0.001189 \mathrm{Nms}$ \\
\hline Total Power & $8.5 \mathrm{~kW}$ & $\begin{array}{l}\text { Inertia } \\
\text { constant }\end{array}$ & $0.01197 \mathrm{~kg} \cdot \mathrm{m}^{2}$ \\
\hline
\end{tabular}

The PV system performances are tested under load variations and sunlight fluctuations as illustrated in Figs. 12 and 13 with a $12 \mathrm{~kW}$ total power. As the PV current is related to incident irradiation, a decrease of solar irradiation decreases the PV current as shown in Fig.17. Since PV electric power is proportional to current, a decrease in PV current reduces PV power output as shown in Figs.14 and 15. The performance of the WEC system under variation of wind speed and load demand is illustrated in Figs. 12 and 16 with a total installed capacity of $8.5 \mathrm{~kW}$. The rotating speed $\left(\omega_{r}\right)$ is proportional to the wind speed $\left(v_{\text {wind }}\right)$, hence the increase of $v_{\text {wind }}$ increases $\omega_{r}$ subjected to a pitch angle controller-controlled limit. As a result, the increasing of $\omega_{r}$ increases the WEC system output power as shown in Figs. 17 and 18. The hybrid system combining the PV and WEC systems is simulated under weather and load variations while supplying $21 \mathrm{~kW}$. The hybrid system allows all climate conditions to produce more energy. When there is wind and sunlight, the energy is both supplied and when there is only sunlight, the energy production is still there. Similarly, when the weather is very cloudy without sunlight and wind presence, the energy production does not stop as it happens for the PV system. The hybrid system provides continuous power over individual systems as shown in Figs.20 and 21.

In the range $(0-1.5 \mathrm{~s})$, the load demand is $0 \mathrm{~kW}$ and the three systems (PV, WEC and PV/WEC) inject the excess power to the grid. In the range $(1.5-2 \mathrm{~s})$, the load $\left(\mathrm{P}_{\text {load }}\right)$ is $40 \mathrm{~kW}$ and the three systems are unable to satisfy the demand and the grid is called to supply the power deficiency. In the range (2-2.5s), $\mathrm{P}_{\text {load }}$ is $20 \mathrm{~kW}$ and the individual systems (PV or WEC) can't supply the load requirement and therefore the grid covers the power deficit. The hybrid system (PV/WEC) supplies the load demand without a need for grid compensation. In the range $(2.5-4.5 \mathrm{~s}), \mathrm{P}_{\text {load }}$ is $10 \mathrm{~kW}$; the PV power varies with irradiation variations. In high irradiation $\left(1000,1200\right.$ and $\left.800 \mathrm{~W} / \mathrm{m}^{2}\right)$, the PV system covers the load demand but for $600 \mathrm{~W} / \mathrm{m}^{2}$ the PV system needs calling the grid to cover the load requirement (deficit of $3 \mathrm{~kW}$ ). The WEC system can't cover the load demand. Despite high wind speed and irradiation variations, the PV/WEC hybrid system covers the load requirement and injects the surplus power to the grid.

During $5 \mathrm{~s}$, the DC voltage is kept at $400 \mathrm{~V}$ as shown in Fig. 22 with small ripples less than 5 V. Figure 23 illustrates the $\mathrm{AC}$ voltage and current which are in phase due to the unity power factor as shown in Fig. 24 with total harmonic distribution (THD) less than 5\% as shown in Fig. 25.

Table 4 shows the results obtained from the PV system, WEC system and a hybrid system (PV/WEC) for various time conditions: available sunlight and wind whistling. It produces a maximum power of $22.5 \mathrm{~kW}$ at $3.9 \mathrm{~s}$.

Table 4. output powers obtained from PV, WECs and the hybrid system (PV/WECs)

\begin{tabular}{c|c|c|c|c|c|c|c|c|c|c}
\hline & \multicolumn{2}{|c|}{$\mathbf{t}=\mathbf{1 . 2 s}$} & \multicolumn{2}{c|}{$\mathbf{t}=\mathbf{1 . 7}$} & \multicolumn{2}{c|}{$\mathbf{t}=\mathbf{2 . 3}$} & \multicolumn{3}{c|}{$\mathbf{t}=\mathbf{3 s}$} & \multicolumn{2}{c}{$\mathbf{t}=\mathbf{3 . 9 s}$} \\
\hline $\begin{array}{c}\text { Powers (kW, } \\
\text { kVAR) }\end{array}$ & $\mathbf{P}$ & $\mathbf{Q}$ & $\mathbf{P}$ & $\mathbf{Q}$ & $\mathbf{P}$ & $\mathbf{Q}$ & $\mathbf{P}$ & $\mathbf{Q}$ & $\mathbf{P}$ & $\mathbf{Q}$ \\
\hline PV & 12.27 & 0.84 & 12.55 & 0.718 & 12.5 & 0.52 & 7.6 & 0.036 & 14.52 & 0.76 \\
WECs & 7.8 & 0.5 & 8.2 & 0.135 & 7.912 & 0.4 & 6.32 & 0.117 & 7.048 & 0.33 \\
Hybrid & 21.45 & 1.02 & 20.18 & 0.97 & 21.37 & 1.08 & 14.27 & 0.29 & 22.5 & 1.09 \\
\hline
\end{tabular}




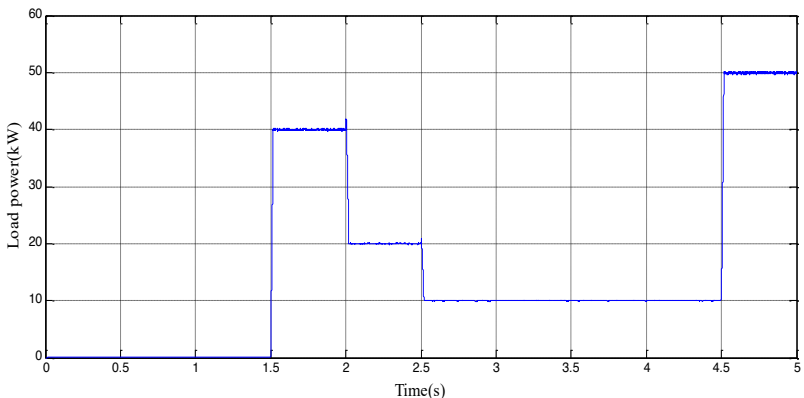

Fig. 12. Load Demand

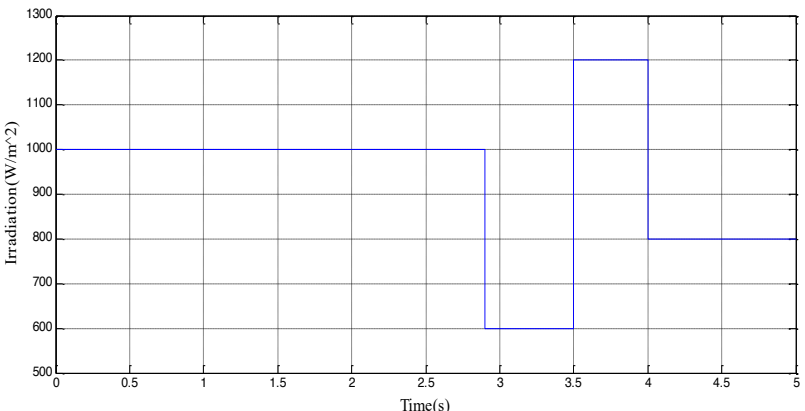

Fig. 13. Irradiation Profile

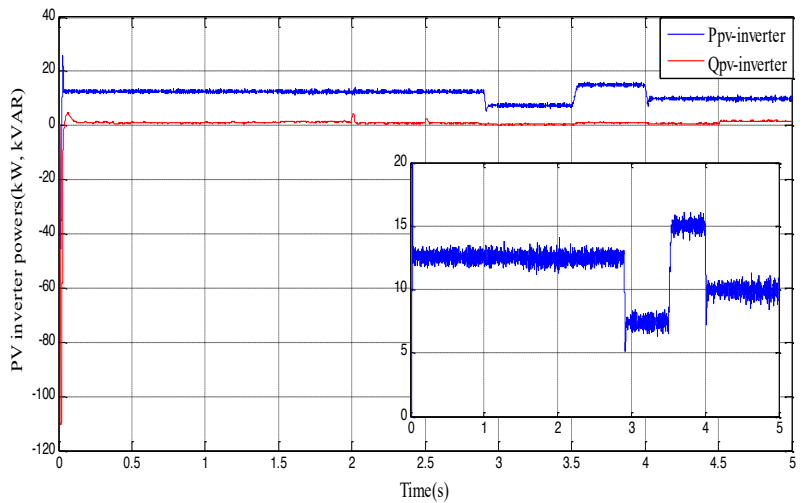

Fig. 14. Inverter powers of PV system

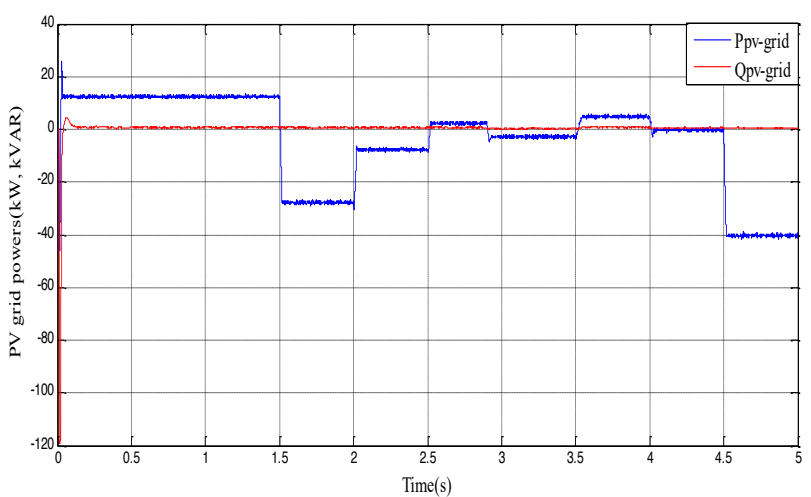

Fig. 15. Grid power of PV system

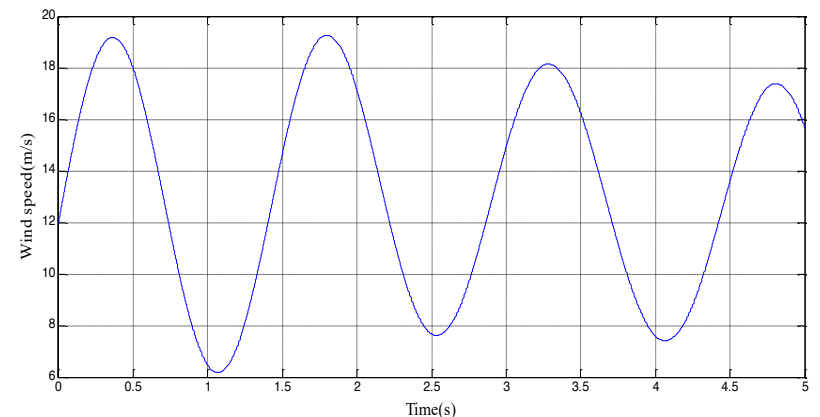

Fig. 16. Wind Speed Profile

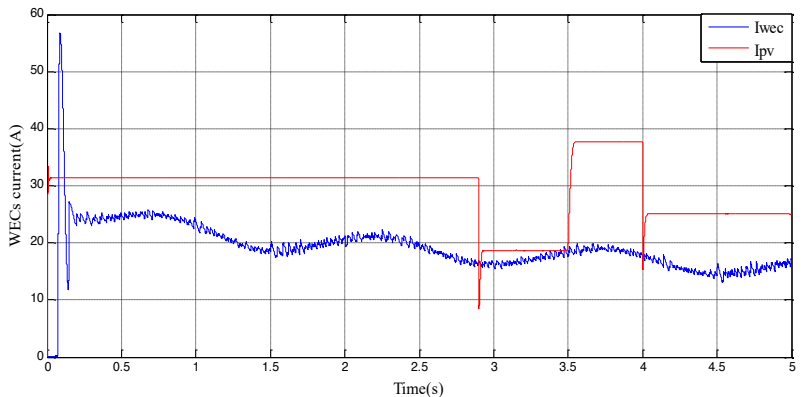

Fig. 17. PV \& WEC Systems Currents

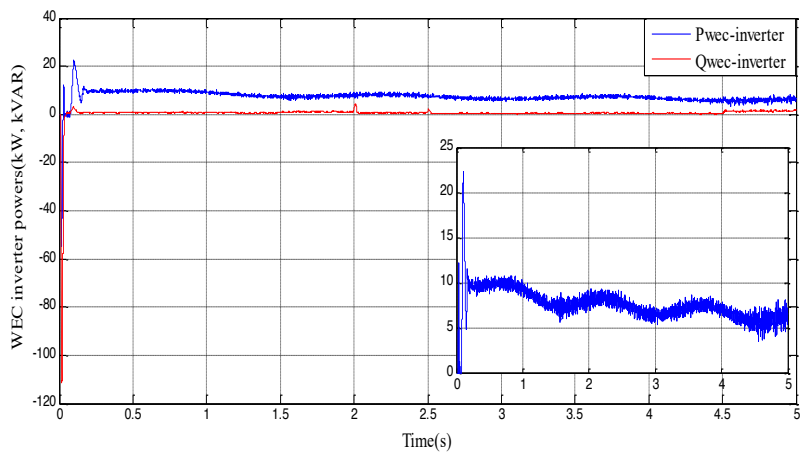

Fig. 18. WEC System Inverter

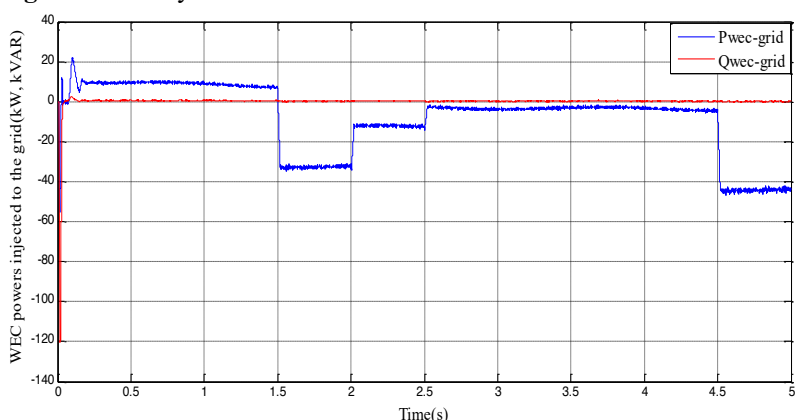

Fig. 19. WEC System Grid power

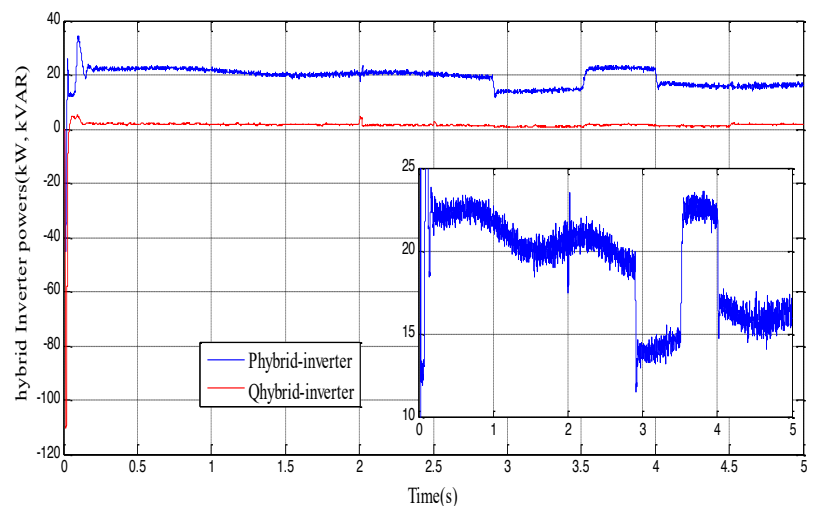

Fig. 20. Hybrid System Inverter Power

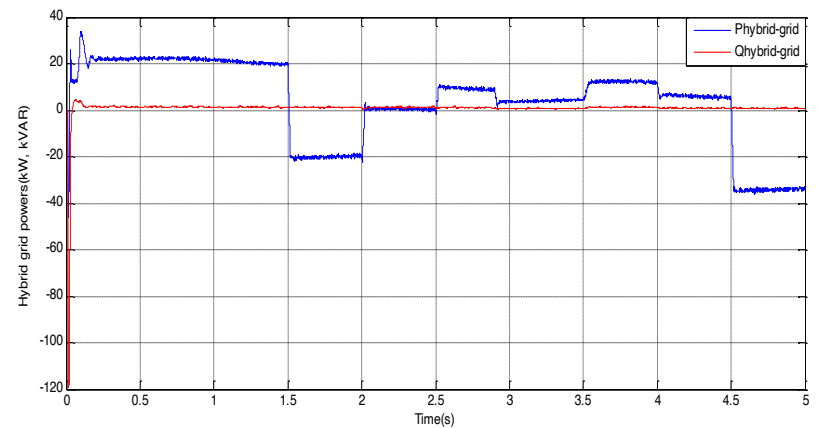

Fig. 21. Hybrid System Grid Power 


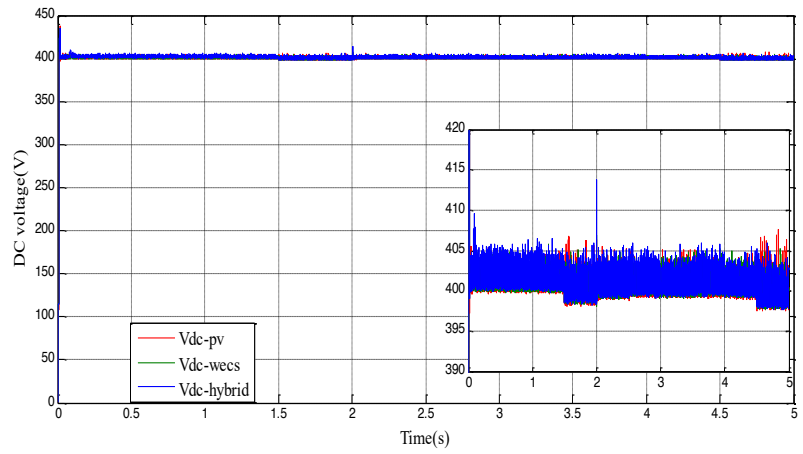

Fig. 22. DC Voltage Output

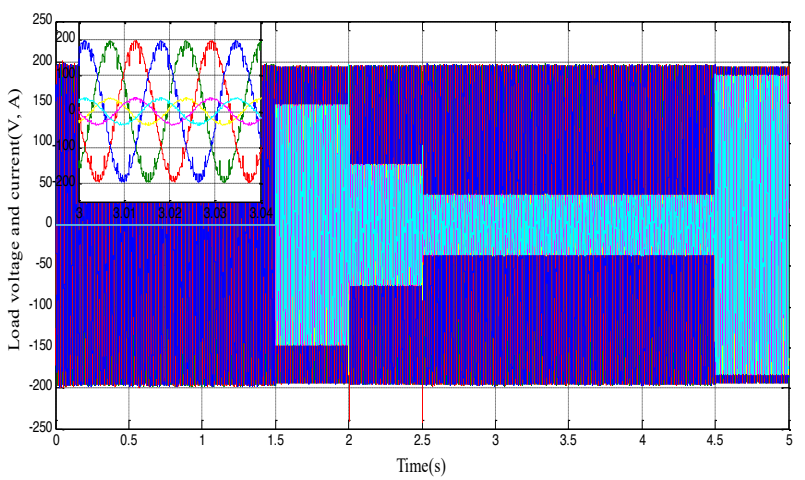

Fig. 23. AC Voltage Output

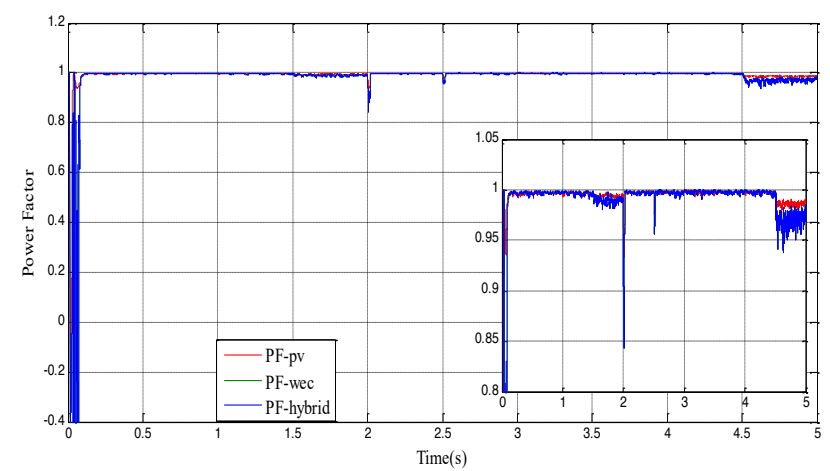

Fig. 24. Power Factor of Each System

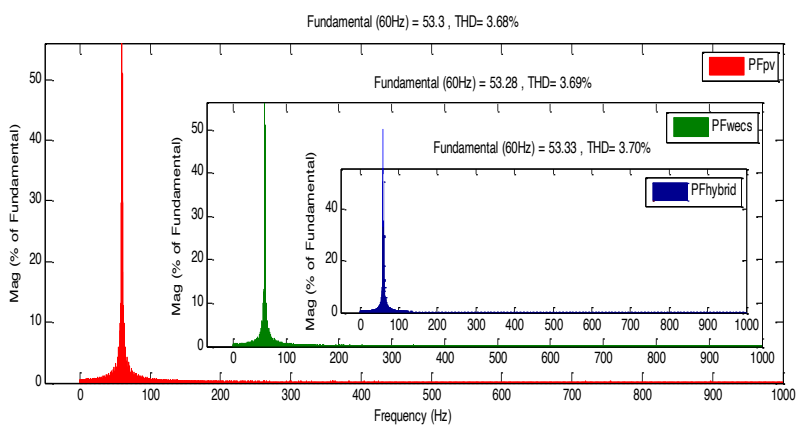

Fig. 25. System Currents and THDs

\section{Conclusion}

In this paper a comparative study of Photovoltaic system, WECs based on permanent magnate synchronic generator (PMSG) and the hybrid system (PV/WEC) is presented to give more reliable energy. The FLC control is applied to extract maximum power under variations in solar irradiation and wind speed. The results demonstrated that the hybrid system supplies more reliable energy regardless of whether varying conditions. The system design reduced the hardware used in the circuit implementation and resulted in cost lowering. The robustness of fuzzy logic control is demonstrated in response to fast changes in weather conditions. The results obtained from different simulations showed that the introduction of the fuzzy control system has largely improved the power system design reliability and efficiency.

This is an Open Access article distributed under the terms of the Creative Commons Attribution License.

\section{References}

1. B. Subudhi, R. Pradhan, "A New Adaptive Maximum Power Point Controller for a Photovoltaic System", IEEE Transactions on sustainable energy, vol. 10,no. 4, pp. 1625-1632, (2019).

2. F. Adamo, F. Attivissimo, A. Di Nisio, and M.Spadavecchia, "Characterization and Testing of a Tool for Photovoltaic Panel Modeling", IEEE transactions on instrumentation and measurement, vol. 60, no. 5, pp.1613-1622, (2011).

3. S. Samal, P. Kumar Hota, "Design and analysis of solar PV-fuel cell and wind energy based microgrid system for power quality improvement", Cogent Engineering, vol.4, no. 1, pp. 1-21, (2017).

4. N. Priyadarshi, V. K. Ramachandaramurthy S. Padmanaban, F. Azam, "An Ant Colony Optimized MPPT for Standalone Hybrid PV-Wind Power System with Single Cuk Converter", Energies, vol. 12, no. 1, (2019).

5. J. M. Carrasco, L. Franquelo, G. J. T. Bialasiewicz, E. Galvan, R. C. P. Guisado, M. a. M. Prats, J. I. Len, , N. Moreno-Alfonso, "Power-Electronic Systems for the Grid Integration of Renewable Energy Sources: A Survey", IEEE transactions on industrial electronics, vol. 53, no. 4,pp. 1002-1016, (2006).

6. J. Yoo, B.Park, K. An, E. A. Al-Ammar, Y. Khan, K. Hur, J. H. Kim,“ Look-Ahead Energy Management of a Grid-Connected Residential PV System with Energy Storage under Time-Based Rate Programs", Energies, vol. 5, no. 4, pp.1116-1134, (2012).
7. S. Pradhan , B. Singh, B. K. Panigrahi, and S. Murshid, "A Composite Sliding Mode Controller for Wind Power Extraction in Remotely Located Solar PV Wind Hybrid System", IEEE transactions on industrial electronics, vol. 66, no. 7,pp. 53215331, (2019).

8. O. Zebraoui, M. Bouzi, “ Improved MPPT controls for a standalone $\mathrm{PV} /$ wind/battery hybrid energy system", International Journal of Power Electronics and Drive System, vol. 1, no. 2, pp. 988-1001, (2020).

9. K. Kumar, N. Ramesh Babu. K.R. Prabhu, "Design and Analysis of RBFN-Based Single MPPT Controller for Hybrid Solar and Wind Energy System", IEEE Access , vol. 5, pp. 15308 -15317, (2017).

10. I. Hamdan, A. M. A. Ibrahim, O. Noureldeen, “ modified STATCOM control strategy for fault ride- through capability enhancement of grid- connected PV/wind hybrid power system during voltage sag", SN Applied Sciences, vol. 2, no. 3, (2020).

11. K. Tazi, M. F. Abbou, F. Abdi, " Performance analysis of microgrid designs with local PMSG wind turbines", Energy Systems, vol. 11, pp.607-639, (2020).

12. B. N. L. Ande, N. R. Tummuru, R. T. Pogulaguntla, B. R. A. Ravada, "Grid-Interactive Power Conversion System for Integrating the PV-Wind Energy Sources", IEEE systems journal, pp. 1-10, (2021). 
Zahira Bouguerra and Arezki Benfdila/Journal of Engineering Science and Technology Review 14 (5) (2021) 180 - 186

13. R. Benadli, B. Khiari, A. Sellami, "Improving grid connected hybrid generation system using an adaptive super-twisting sliding mode and predictive current control strategy", control engineering and applied informatics, vol.21, no.2 pp. 64-75, (2019).

14. A. A. BelKhair, J. Rahebi, and A. Abdulhamed M. Nureddin, "A Study of Deep Neural Network Controller-Based Power Quality Improvement of Hybrid PV/Wind Systems by Using Smart Inverter", International Journal of Photoenergy, vol. 16, pp. 1-20, (2020).

15. L. Zhua, Q. Li, M. Chen, K. Cao, Y. Sun, "A simplified mathematical model for power output predicting of Building Integrated Photovoltaic under partial shading conditions", Energy Conversion and Management, vol. 180 , pp. 831-843, (2019).

16. Y. Zhu , J. Fei, “Adaptive Global Fast Terminal Sliding Mode Control of Grid-connected Photovoltaic System Using Fuzzy Neural Network Approach", IEEE Access, vol. 5, pp. 9476-9484, (2017).

17. K. Kumar, N. Ramesh Babu, K.R. Prabhu, "Design and Analysis of RBFN Based Single MPPT Controller for Hybrid Solar and Wind Energy System”, IEEE Access, vol. 5, pp. 15308 -15317, (2017).

18. N. Bouaziz, A. Benfdila , A. Lakhlef, "A model for predicting photovoltaic module performances", International Journal of Power Electronics and Drive System, vol. 10, no. 4, pp. 19141922, (2019).

19. S.Aissou, D. Rekioua, N. Mezzai, T. Rekioua, S. Bacha, "Modeling and control of hybrid photovoltaic wind power system with battery storage", Energy Conversion and Management, vol. 89,pp. 615-625, (2015).

20. M., Pucci, M. Cirrincione, "Neural MPPT control of generators with induction machines without speed sensors", IEEE
Transactions on Industrial Electronics, vol. 58, no. 1,pp. 37-47, (2011).

21. A. Rolan, , A. Luna, , G. Vazquez, D. Aguilar, G. Azevedo, "Modeling of a Variable Speed Wind Turbine with a Permanent Magnet Synchronous Generator", IEEE International Symposium on Industrial Electronics, Korea, (2009).

22. Y. Zhao, C. Wei, Z. Zhang, W. Qiao, "A Review on Position/Speed Sensorless Control for Permanent-Magnet Synchronous Machine-Based Wind Energy Conversion Systems", IEEE journal of emerging and selected topics in power electronics, vol. 1, no. 4, (2013).

23. N. Tidjani, A. Guessoum, "Augmented robust T-S fuzzy control based PMSG wind turbine improved with $\mathrm{H} \infty$ performance", International Journal of Power Electronics and Drive Systems, vol. 12, no. 1, pp. 585-596, (2021).

24. I. Ui Haq, Q. Khan, I. Khan, R. Akmeliawati, K. Soopy Nisar, I. Khan, "Maximum Power Extraction Strategy for Variable Speed Wind Turbine System via Neuro-Adaptive Generalized Global Sliding Mode Controller", IEEE Access, Vol. 8, pp. 128536 128547, (2020).

25. F. Blaabjerg and K. Ma, "Future on power electronics for wind turbine systems", IEEE Journal of Emerging and Selected Topics in Power Electronics, vol. 1, no. 3, pp. 139-152, (2013).

26. T. L. Van, T. H. Nguyen, D.C. Lee, "Advanced Pitch Angle Control Based on Fuzzy Logic for Variable-Speed Wind Turbine Systems", IEEE Transactions on energy conversion, vol. 30, no. 2, 578-587, (2015).

27. T. Pidiiti, and G. T. Ram Das, "Power Maximization and Control of PMSG Wind Energy System without Wind Speed Sensors", International Journal of Control Theory and Applications, vol. 10 , no. 25, pp. 253-260, (2017). 